\title{
НОСТАЛЬГИЯ В ФИЛЬМЕ НИКИТЫ МИХАЛКОВА УРГА: ТЕРРИТОРИЯ ЛЮБВИ
}

\author{
NOSTALGIA IN URGA: CLOSE TO EDEN \\ BY NIKITA MIKHALKOV
}

\author{
NATALIA KAŹMIERCZAK
}

\begin{abstract}
AвSTRACT. The article is concerned with the interpretation of Nikita Mikhalkov's artistic method as fiction phenomenology of nostalgia. Nostalgia is associated mainly with the reflective yearning for the past.

Keywords: fiction phenomenology, nostalgia, Nikita Mikhalkov, Urga

Natalia Kaźmierczak, Uniwersytet im. Adama Mickiewicza w Poznaniu, Poznań - Polska nataliakazmierczak@gmail.com
\end{abstract}

ORCID ID: 0000-0002-7589-3320

Феномен ностальгии в социологических [Чикишева 2009: 267-277] и психологических [Фенько 1993] исследованиях воспринимается как чувство, связанное, прежде всего, с обращением к прошлому, часто идеализируемому времени и пространству, которых уже нет. Светлана Бойм выделяет две модели ностальгии: реставрирующая ностальгия, направленная на переживаемое событие и связанное с его идеализацией, и рефлексирующая ностальгия, сосредоточенная на самом процессе переживания и переоценки прошлого [Бойм 2013].

В философском осмыслении ностальгия определяется или как своеобразное отношение к прошлому, дающее возможность критики настояшего, или же как чувство тоски по целому, влечение к миру - „бытию в целом", подразумевающее прежде всего не стремление к овладению бесконечным, а близость другого [Иванов 2007]. В работах Мартина Хайдеггера рассуждения о ностальгии обращены к искусству как основной сфере ее проявления [2013: 28]. Искусство, понимаемое как свободное „творение”, является „созидающим охранением истины”, местом проявления сущего [Хайдеггер 1935-1936]. Следовательно, сознательное переживание ностальгии в процессе восприятия искусства должно приблизить человека к открытию тайны бытия.

В перспективе избранной темы ценные наблюдения содержит также анализ ностальгии в контексте постметафизической философии исто- 
рии Ильи Дёмина [2012: 16-25]. Положения ученого заключаются в подходе к феномену ностальгии не как опыту или чувству, а как „экзистенциальному (онтологическому) расположению", проявляющему себя во времени и относящемуся не только к прошлому.

Экзистенциально-онтологически понимаемое расположение есть расположение бытия-в-мире в целом. История или бытие-бывшествующим есть лишь один из трех структурных моментов бытия-в-мире. Ностальгическому бытию-к-бывшему соответствует ностальгическое бытие-в-настояшем (настаивание-на) и ностальгическое заступание в будущее (настаивание) [Дёмин 2012: 24].

Фильмы Никиты Михалкова рассматриваются главным образом как выражение ностальгии, обращенной к прошлому [Beumers 2005; Demby 2001: 102-115; Demby 2003], как попытка поиска утраченной экзистенциальной гармонии [Demby 2009]. Указанные исследования кинотворчества русского режиссера описывают феномен ностальгии согласно с общим значением этого понятия в языке, т.е. как тоски по родному дому, тоски о минувшем и о безвозвратно утраченном [Кузнецов 1998: 658]. Интерпретация ностальгии не только как чувства, а также как определенного переживания, опыта темпоральности бытия, полагаем, расширит спектр возможных прочтений интересующего нас произведения киноискусства.

Глубокое творческое осмысление ностальгии в фильме Михалкова Урга обосновывает предпосылки для анализа данного произведения в ключе художественной феноменологии. Художественная феноменология понимается как „имплицитно содержащаяся в способе восприятия мира, в поэтике художественного текста" [Железняк 2010: 110]. Основополагающим творческим методом, открывающим зрителю сущность ностальгии, считаем использование столкновения (смыслового монтажа) противоположностей в измерении художественного времени и пространства.

Фильм рассматриваем с точки зрения филолога, т.е. как художественный текст [см. Demby 2009]. При таком подходе исследуемое прочитывается, во-первых, как целое, не сводимое к сумме составляющих, во вторых - подразумевается авторская позиция режиссера и, в третьих - интерпретация фильма не представляет собой поиска подтверждения или же негации подлинности изображаемого, а является попыткой выявить художественную стратегию режиссера.

Центральным смыслообразующим мотивом в рассматриваемом фильме является дорога, понимаемая (вслед за Татьяной Щепанской) как конструируемый культурой текст [2003: 11-13]. Динамика движения между своим и чужим миром, указывающая на проблему преодоления духовной 
разъединенности бытия и расколотости сознания, создает место столкновения аксиологических контрастов. Пребывание в пути прочитываем как процесс поиска жизненного ориентира, духовного роста, обращение к истокам своей культуры. Указанная перцепция этого мотива реализуется в образе монгольского пастуха Гомбо. Его поездка в город за презервативами по мере развития сюжета теряет поверхностно иронический оттенок и становится своего рода паломничеством с целью освобождения от эгоистического самоутверждения.

Художественная конструкция второго, путешествующего героя, прежде всего соответствует концепту „пришельца”. Русский шофер Сергей попадает в новый мир и пытается к нему адаптироваться, занять положение „своего”. Художественная структура этого героя основана на пребывании в переходной, между домом и дорогой, позиции „гостя”. Появление гостя размыкает домашнее пространство монгольской юрты и

трансформирует пространство дороги и дома, между ними образуется промежуточное пространство со смешанными свойствами. В домашних событиях видится дорога, а в дорожных - дом. Разрушается разделяющая их символическая граница, открывая дом влияниям дороги, иногда разрушительным. Обычаи встречи/гостеприимства призваны восстановить границу: адаптировать пришельца к домашним нормам и образу жизни так, чтобы он утратил качество чужести и больше не был проводником для чуждых сил [Щепанская 2003: 363].

Художественная композиция фильма Урга обусловливает интерпретацию приезда гостя в более широком, эсхатологическом смысле. В юрте Гомбо, понимаемой как модель космоса, появляется „чужой” - воплощение разрушительных сил. Благодаря соблюдению ритуалов, очищения, освоения и ревитализации носитель хаотического начала (дорога) подчиняется упорядочивающему началу (дом). Хаос, однако, не изживается из домашнего пространства, появляющиеся в юрте предметы чужого мира (телевизор) предвещают постепенное поглощение этого пространства хаосом.

Приведенная интерпретация обычаев, связанных со столкновением домашнего и дорожного пространств, тяготеет к универсальному измерению, соответствующему не только русской культуре. Перцепция прибытия гостя как представителя внешнего, неосвоенного пространства, требующего исполнения определенного этикета, указаны в анализе традиций монгольской культуры Натальи Жуковской [2015: 78-79]. Ритуалы, связанные с гостеприимством: омовение перед входом в юрту и угощение, исполняющие функцию освоения неизвестного, т.е. познания истинных намерений приезжего и принятия его в семейный круг как „своего” - в фильме имеет односторонний характер. Сергей не может выйти из 
положения „гостя", единственное пространство его функционирования дорога и связанные с ней локусы: отели, бары и т.д. Полное отсутствие одомашненного пространства в чужом мире детерминирует чувство ностальгии как тоски по родному.

В художественной структуре хронотопа фильма Урга пребладает, однако не пространственное, а темпоральное начало. Поэтика времени реализуется и на сюжетно-фабульном, и на смысловом уровнях фильма. Все происходящее „рассказано” зрителю, четвертым потомком Гомбо и Падмы - Тэмуджином, о существовании которого узнаем в лишь в последних кадрах фильма. Встреча представителей различных культурных пространств (Сергея и Гомбо) выстраивает поле для осуществления авторской конщепции переживания времени. Образы главных героев произведения можно обоснованно рассматривать как временные формы [см. Мариевская 2015: 135-140].

Формирование времени главных героев этого кинопроизведения подчинено их желанию осуществить определенные цели. Поэтому сюжетно-образная система развертывается в последовательности, соответствующей реализации жизненной цели героя. История Сергея подчинена стремлению к достижению личных выгод: улучшения бытовых условий, увеличения заработка, следования поверхностным ценностям, связанным с городом, олицетворяющим в фильме эгоизм и ведущий к отчуждению цивилизационный прогресс. Гомбо противопоставлен Сергею в аксиологическом плане - герой руководствуется высокими нравственными ценностями. Стремления Гомбо направлены прежде всего на духовный рост и поиск смысла жизни. Конечно, реализиция намерений Сергея и Гомбо, обуславливающая обращенность к будущему, не исчерпывает темпоральности этих образов.

Время Сергея имеет характер всеобъемлющего „сейчас”, его настоящее конструируется желанием жить „не хуже других", вынуждающим его к поискам дополнительных возможностей заработать. В этом месте важно подчеркнуть, что Сергей, безусловно, положительный герой, с его прошлым связаны духовные ценности русской культуры. Герой, однако, полностью увяз в настоящем, его путь не приведет к ответу на приобретающий метафизический характер вопрос жены: „что мы тут делаем?” В таком понимании времени (путь, развитие) у Сергея нет будущего, а связь с прошлым полностью утрачена. Контраст образов шумного и пестрого настоящего с воспоминанием - спокойным, величественным образом церкви на фоне черно-белого зимнего пейзажа в некотором смысле визуализирует ностальгию, воспринимаемую как чувство потери и утраты целостности.

Временная конструкция образа Гомбо является более сложной и имеет „вертикальную” структуру. Семья Гомбо живет в степи, согласно рит- 
му природы и в дали от центра материальной цивилизации. Настоящее этого героя вбирает в себя прошлое - связь с предками и будущее - мысль о потомке. Вертикальное построение времени этого героя иллюстрирует прежде всего сон в степи, после поездки в город. Во сне Гомбо видит гнев предков, а сожжение грузовика Сергея указывает непосредственно на высший характер духовной традиции и бесполезность материальных богатств. Будущее проецируется на поиск разрешения вопроса о зачатии ребенка. В таком построении ностальгия понимается как своеобразное пребывание в состоянии надежды на откровение, т.е. пребевание в состоянии неполноты, несовершенства.

Указанные временные конструкции героев помещены режиссером в сферу прошлого, в сферу воспоминаний сына Гомбо. Время прошло, и все переменилось. Тэмуджин, рассказывая историю своего происхождения, упоминает, что живет в городе, а в том месте, где его отец воткнул в землю ургу, теперь возвышается огромная труба, видимая из окна квартиры персонажа. Тэмуджин не тоскует о прошлом и не задумывается над смыслом жизни, его планы на будущее имеют увеселительно-бытовой характер. По своей временной конструкции этот персонаж близок образу Сергея, но он полностью порабощен „городом”, живет настоящей минутой и чувство ностальгии ему совершенно чуждо. В структуре фильма этот образ исполняет роль своеобразного „минус-приема”. Ожидаемому зрителем процессу перехода ценностей от отца к сыну не дано осуществиться. В конце фильма перед зрителем появляется „никто” - совершенно пустой образ искорененного человека без прошлого и будущего. Такое завершение кинопроизведения создает особое эмоциональное напряжение, поскольку накапливаемый на протяжении всего фильма ценностный потенциал в финале не находит пути реализации, все возможности его осуществления привязаны к прошлому. Благодаря этому напряжению в фильме конституируется „обратная смысловая перспектива", переносящая центр (феномен ностальгии) за рамки кадра, в сферу зрителя.

Условия для конституирования художественной феноменологии ностальгии образуются также при помощи отдельных визуальных и звуковых знаков-символов, наделенных, как правило, противоречивой, а точнее, изменяющейся с течением художественного времени фильма семантикой. Поэтому эти знаки-символы должны восприниматься не как данные заранее, статичные образы, а в их смысловом становлении и динамике развития в целом художественного фильма.

В звуковом ряде фильма значимое место занимает шум ветра. Творческое осмысление Михалковым динамики природной стихии выстраивает широкое ассоциативное поле значений. Сопутствующий начальным 
кадрам, указывающим на степь, ветер, понимается главным образом как выражение созидательного начала [Тресиддер 1999] и свободы. В сценах, представляющих сон Гомбо и воспоминание Сергея о церкви ветер прочитывается как голос минувших поколений, голос предков, а в перспективе финала фильма, предостережение, выражение тревоги и предвестие грядущих перемен. Трансформация шума ветра в звонок телефона в конщовке фильма указывает на разрыв во времени, разрушение связи с прошлым и будущим.

Заглавная урга, представляющая собой палку с петлей, вбиваемая в землю в момент праздника любви и зачатия ребенка, ассоциируется непосредственно с осью мира, центром космоса, объединяющим и упорядочивающим началом. Ургу сменяет труба завода, а „территория любви" сменяется территорией производства. В силу этого объединяющая ось мироздания становится знаком потери целого и разобщенности человеческого бытия.

Функция рассматриваемых образов заключается, прежде всего, в пробуждении в зрителе воспоминания об изначальном счастье и его утрате, вследствие „падения” человека, определившего онтологическую перемену собственного состояния человека, а также космический раскол" [Элиаде 1996: 63]. Следовательно, восприятие указанных образов в их смысловом становлении создает особый (субъективный) эмоциональный фон для возможности конституирования ностальгии, понимаемой как экзистенциальное состояние современного человека.

\section{Библиография}

Бойм С. 2013. Будущее ностальгии, „Неприкосновенный запас”, № 3 (89), электронный pecypc: http:/ / magazines.russ.ru/nz/2013/3/11s.html\#_ftn5 (доступ 13.08.2017).

Дёмин И. В. 2012. Феномен ностальгии в горизонте постметафизической философии истории, „Вестник Самарской гуманитарной академии", № 1 (11), с. 16-25.

Железняк В. Н. 2010. Художественная феноменология М. Пруста, „Вестник Пермского Университета. Российская и зарубежная филология", № 3 (9), с. 110-115.

Жуковская Н. Л. 2015. Традиции монгольской культуры в контексте представлений о пространстве и времени [в:] Ю. Ф. Кузьмин (ред.), Россия и Монголия: новый взгляд на историю (дипломатия, экономика, культура), Иркутск: Байкальский государственный университет экономики и права, с. 75-91.

Иванов А. 2007. Прогрессивная ностальгия, электронный ресурс: http://xz.gif.ru/ numbers/65-66/aleksandr-ivanov/ (доступ 12.08.2017).

Кузнецов С. А. (ред.) 1998. Большой толковый словарь русского языка, Санкт-Петербург: Норинт.

Мариевская Н. Е. 2015. Время в кино, Москва: Прогресс-Традиция.

Трессидер Д. 1999. Словарь символов, электронный ресурс: https://www.booksite.ru/ localtxt/tre/sid/der/tresidder_d/slovar_sim/index.htm (доступ 12.08.2017). 
Фенько А. Б. 1993. Психология ностальгии, „Московский психотерапевтический журнал", Москва, № 3, электронный ресурс: https://psyjournals.ru/files/25786/ mpj_1993_n3_Fenko.pdf (доступ 13.08.2017).

Хайдеггер М. 1935-1936. Исток художественного творения, электронный ресурс: http:/ / www.gulliverus.ru/gvideon/?article=43275 (доступ 13.09.2017).

Хайдеггер М. 2013. Основные понятия метафизики. Мир-конечность-одиночество, перевод В. В. Бибихина, Л. В. Ахутина и А. П. Шурбелева, Санкт-Петербург: Владимир Даль.

Чикишева А. С. 2009. Феномен ностальгии в постсоветской массовой культуре, [в:] Д. Л. Спивак (ред.), Фундаментальные проблемы культурологии 87 томах, т. 6, Москва-Санкт-Петербург: Новый хронограф, Эйдос, с. 267-277.

Щепанская Т. Б. 2003. Культура дороги в русской мифоритуальной традииии XIX-XX вв., Москва: Индрик.

Элиаде М. 1996. Мифы, сновидения, мистерии, перевод А. П. Хомик, Москва: Рефл-бук.

Beumers B. 2005. Nikita Mikhalkov: Between Nostalgia and Nationalism, London, New York: I.B. Tauris \& Co Ltd.

Demby Ł. 2001. Koniec wieku XX. Bohaterowie filmów Nikity Michałkowa w świecie nowoczesnych wartości, „Kwartalnik Filmowy”, № 34, c. 102-115.

Demby Ł. 2003. Nikita Michałkow. Odmiany czasu i przestrzeni, [в:] G. Stachowna, J. Wojnicka (ред.), Autorzy kina europejskiego, Kraków: Rabid.

Demby Ł. 2009. Harmonia świata: twórczość filmowa Nikity Michałkowa. Kraków: Rabid. 
